\title{
HOW THE RHINO GOT THE HUMP
}

I can remember what I was. Whence come these ropes and chains?

Why is Kariba rising? It's two months off to the rains.

I have faced the spears of tribesmen: I have charged the hunter's gun :

I have stood the worst of the summer's thirst when the pools have dried in the sun.

But damn these men with syringes when, on a man-made Ararat, They get me down with a tranquillizer, and fend me off with a hat!

In the years of Allan Quatermain, Selous and Hemingway

I could choose to fight or fade from sight to fight on another day. They wanted my head for a trophy, or my hide for sjambok whips,

Or my final throes in a gush of prose for their various authorships.

Or ... it's quite an accepted story that this nose-ridge horn of ours

Produces a ground-up glory of aphrodisiac powers.

Well, so much the better for humans, and so much the worse for us

If the Lord disposes above our noses this death-fraught, birthfraught plus.

We took these men and menaces then gallantly in our stride

And as three-ton bush-bred monarchs worthily lived ... a and died.

The ultimate degradation was for those of our species whose

Unfortunate fates were to go into crates and get emptied out into zoos.

But now . . . is my face red, brothers ? . . they have captured and let me go,

And there isn't a mark on me, hide nor hair, as a battle scar to show.

The African veldt, I have always felt, lacks peaks (it is not like Darien) :

Floods may be O.K. for a hippo, say, but a rhino is non-riparian.

I stood on a mound of diminishing ground and men approached on a raft;

They noosed my feet with ropes and chains and hobbled me fore and aft.

I kicked and fought as the waters rose, but they tipped me on to my side 
And jabbed a needle of tranquillizer under my wrinkled hide.

Did I feel like a jungle monarch then, with the juice lapping into my brain?

I did not, and I know I can never feel like a jungle monarch again.

A white game ranger called Fothergill (not Strickland or Carruthers)

Had a black syringe-kit-bearer-assistant with him, and several others.

And Fothergill, I noticed till I got cross-eyed and dopey,

Was wearing a floppy linen hat instead of the proper topee.

And instead of a bush-shirt bandoliered with cartridges in pouches,

He was bare to the waist and in shorts and shoes, as the photograph of it vouches.

(And that wasn't the least depressing thing in the whole depressing mess ...

A cameraman with flash-in-the-pan taking photographs for the press!)

Well, it seems that my " shot" of juice was not so strong as my captors hoped.

They'd ferried me over to safe dry land and dumped me, as they thought, doped,

Untied my feet and, their job complete, had turned and started to pack

To be ready to pole their raft away . . . when I rose with a roar to attack!

But the waters caught my legs athwart, and a mist was over my eyes,

And I thought that my head must be made of lead and treble its normal size.

I was groggy still, and Fothergill, to my deep, lifelong disgrace,

Was able to stop my headlong rush by flapping his hat in my face!

I have often felt that the African veldt was losing its mystery With Armand and Michaela, Van der Post and all of us on TV. But ... caught and bound and left on the ground and pushed in the face with a hat,

And a subpachydermatous Mickey Finn ... I'll never get over that!

Richard Usborne.

Reproduced by permission of PUNCH. 